\title{
An investigation on allele frequency at the CSN1S2 locus and its relationship with milk parameters in the Sarda goat*
}

\section{G.M. Vacca ${ }^{1,3}$, H. Ouled Ahmed Ben Ali², M. Pazzola ${ }^{1}$, M. Sanna ${ }^{1}$, M.L. Dettori ${ }^{1}$ and V. Carcangiu ${ }^{1}$}

\author{
${ }^{1}$ University of Sassari, Department of Animal Biology \\ via Vienna 2, 07100 Sassari, Italy \\ ${ }^{2}$ Tunisian Institute of Veterinary Research \\ Rue Djebel Lakhdhar 20 - La Rabta, 1006 Tunis, Tunisia
}

(Received 10 January 2009; revised version 19 March 2009; accepted 6 November 2009)

\begin{abstract}
The aim of the study was to assess allele frequencies at the CSN1S2 locus in the Sarda goat and the effects of the genotype on milk composition. Two hundred twenty Sarda goats from 20 farms were selected. Individual blood and milk samples were collected during the middle of lactation and daily milk yield was registered. Fat, protein and lactose percentage, freezing point, $\mathrm{pH}$, somatic cell count and total mesophilic count were measured. DNA was analysed with different methods based on PCR. Allele frequencies, the Hardy Weinberg (HW) equilibrium and the correlations between milk yield and composition and the genotypes were calculated. F (0.400) and A (0.330) alleles showed the highest frequency. D and 0 alleles were not found. Genotype frequencies were the following: AA, 0.136; AB, 0.009; AC, 0.082; AE, 0.032; AF, 0.264; CC, 0.023; CE, 0.023; CF, 0.250; EF, 0.077; FF, 0.105 . The population was in HW disequilibrium. No link between the genotypes and milk yield, chemical, physical and cytological parameters was found.
\end{abstract}

KEYWORDS: CSN1S2 locus, milk, goat

\footnotetext{
* Supported by RAS (fondi CIPE APQ P5a, Biodiversità Animale)

${ }^{3}$ Corresponding autor: e-mail: gmvacca@uniss.it
} 


\section{INTRODUCTION}

Breeding and the improvement of autochthonous breeds is an effective choice to improve animal husbandry in some developing areas. Natural and typical products are also guaranteed by the preservation of biodiversity in livestock species and their breeding habitat (Boyazoglu et al., 2005). The Sarda is the autochthonous goat from the island of Sardinia and, with about 200,000 heads, it is considered a large reservoir of biodiversity. Animal products from the Sarda goat could safeguard this breed and the whole goat breeding activity, which plays an important economic and social role in Sardinia (Carcangiu et al., 2006). Sarda selection schemes have still not considered the qualitative traits of the milk, such as the genetic characterization of casein variants, which are correlated with the chemical and technological properties of goat milk (Barbieri et al., 1995). The study of these characters in other species and breeds has allowed the enhancement in value of their products. The $\alpha \mathrm{s}_{1}, \alpha \mathrm{s}_{2}, \beta$ and $\kappa$-caseins are encoded by four strictly associated genes. In the bovine species, they are located on chromosome 6, within a $250 \mathrm{Kbp}$ DNA segment, in the following order: CSN1S1 (encoding $\alpha \mathrm{s}_{1}$-casein), CSN2 ( $\beta$-casein), CSN1S2 ( $\alpha \mathrm{s}_{2}$-casein), CSN3 ( $\kappa$-casein) (Threadgill and Womack, 1990). The organization of the casein gene cluster is highly conserved among mammals, although high qualitative and quantitative variability have been recorded between the species (Rijnkels, 2002). Several studies evidenced that the four goat casein genes are polymorphic (Caroli et al., 2006). This variability is an important factor in genetic improvement and permits a diversification of milk production, thus allowing choice for the right genetic basis for the production of cheese, drinking or hypoallergenic milk (Ramunno et al., 2007). $\alpha \mathrm{s}_{2}$-casein is a phosphoprotein of 208 amino acids and is one of the most important allergens in milk (Jarvinen, 2002). El-Agamy (2007) stated the risk of allergy reaction is diminished as regards goat milk as its milk proteins show a high homology with human ones. Moreover, $\alpha s_{2}$-casein is absent in human milk (Martin et al., 1996), although two potential $\alpha_{2}$-like casein genes have been identified within the human casein gene cluster, named CSN1S2A and CSN1S2B. The DNA transcript of CSN1S2A has been detected in the human lactating mammary gland RNA, but it probably does not produce a stable protein chain. Specific DNA transcripts of CSN1S2B have not been found (Rijnkels et al., 2003). In cattle, CSN1S2 is the longest casein gene (about 18,5 Kbp) and it is organized in 18 exons, whose length varies between 21 and 266 bp (Groenen et al., 1993). In goats, seven alleles have been identified at the CSNIS2 locus and these are associated with three different

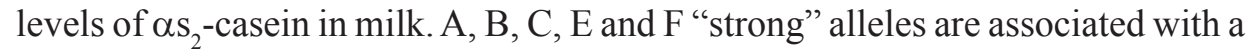
normal ${\alpha \mathrm{s}_{2}}_{2}$-casein content (about $2.5 \mathrm{~g} / 1$ for allele), D allele with an intermediate content $(1.5 \mathrm{~g} / \mathrm{l})$ and the "null" allele 0 in homozygosis is associated with the 


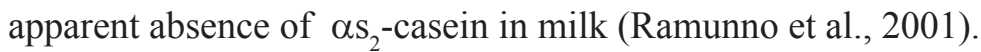

The aim of this research was to analyse the genetic structure at the CSN1S2 locus in Sarda goats and the possible correlations between its genotype and milk parameters.

\section{MATERIAL AND METHODS}

\section{Animals and samples}

A total of 220 lactating goats from 20 goat farms (11 goats in each farm) located in central Sardinia (Italy), were randomly chosen. Farms were similar in animal management which was in accordance with traditional Sardinian goat farming: goats were exclusively fed pasture on a Mediterranean shrubland, without any concentrate supplementation and the pasture composition was similar among the farms; they were hand-milked once daily in the morning and in all the flocks the udder was not cleaned before milking; reproduction was based on natural mating and sex ratio was $1 / 18$; kids were milk fed by their dams and weaned when they were about six weeks old; some pens and a shelter for milking were the only facilities on the farms. During the intermediate stage of lactation (between day 100 and 110 after kidding) individual milk samples were collected from all goats in $200 \mathrm{ml}$ sterile plastic containers and were transported at $+4^{\circ} \mathrm{C}$ to the laboratory within $2 \mathrm{~h}$. Plastic containers were filled after the first stream of milk had already been rejected. On the same day, individual daily milk yield in grams was registered and a blood sample was taken by one puncture from the jugular vein of each animal, using vacuum tubes with EDTA as anticoagulant (BD Vacutainer Systems ${ }^{\circledR}$, Belliver Industrial Estate, Plymouth, UK).

\section{Milk analysis}

Milk samples were analysed for $\mathrm{pH}$ and total protein, fat, lactose and urea content using an I.R. spectrophotometer (Milko-Scan 133B Foss Electric ${ }^{\circledR}$, DK-3400 Hillerød, Denmark) according to the International Dairy Federation (IDF) standard (IDF 141C:2000); somatic cell count (SCC) using an automatic cell counter (Fossomatic 90, Foss Electric ${ }^{\circledR}$ ) according to IDF 148A:1995; total mesophilic count (TMC) using a Bacto-Scan, Foss Electric ${ }^{\circledR}$ (IDF 358:2000); freezing point (FP) in Hortvet degrees $\left(\mathrm{H}^{\circ}\right)$ by a thermistore cryoscope (IDF 108:2002). 


\section{PCR amplification and polymorphism identification}

The DNA was extracted from leukocytes using the Puregene ${ }^{\circledR}$ DNA isolation kit (GENTRA) and analysed by means of different PCR methods. The CSN1S2 B allele, compared to the A allele, shows a G10A transition at exon 9, which causes a Glu $_{64} \rightarrow$ Lys substitution in the mature protein, while the mutational event characterizing the $\mathrm{C}$ variant is a transversion $\mathrm{A} 5 \mathrm{~T}$ at exon 16, which determines the substitution Lys $_{167} \rightarrow$ Ile (Bouniol et al., 1994). The presence of CSN1S2 A, B and $\mathrm{C}$ alleles was investigated by Multiplex Allele Specific PCR (Ramunno et al., 2000), utilizing in the first reaction the two primer pairs: B1X/B1Z and $C 2 X / C 2 Z$, which selectively amplified the CSN1S2 A allele, and in the second PCR reaction the two primer pairs: $\mathrm{B} 1 \mathrm{Y} / \mathrm{B} 1 \mathrm{Z}$ and $\mathrm{C} 2 \mathrm{Y} / \mathrm{C} 2 \mathrm{Z}$, which amplified the CSN1S2 B and $\mathrm{C}$ alleles, respectively. The CSN1S2 $\mathrm{D}$ and 0 alleles were investigated by PCR-RFLP (Ramunno et al., 2001). The CSNIS2 D allele is characterized by the deletion of $106 \mathrm{bp}$ spanning from the $11^{\text {th }} \mathrm{nt}$ of exon 11 to $95 \mathrm{nt}$ of the following intron. This allele was detected by PCR amplification of a $301 \mathrm{bp}$ long fragment containing the $11^{\text {th }}$ exon, with the primer pair CASDF/CASDR; the D allele, if present, produces a fragment of $195 \mathrm{bp}$. The same PCR amplified fragment allowed the detection of the CSN1S2 0 allele, after digestion with the restriction enzyme NcoI, being the 0 allele characterized by a transition G80A at exon 11, which causes the formation of a premature stop codon. The nucleotide variation characterizing the CSN1S2 E allele (C83G) occurs at exon 16 and results in an amino acid substitution $\mathrm{Pro}_{193} \rightarrow$ Arg in the mature protein. It was detected by PCR amplification (primers CASEF/CASER) and restriction with enzyme NlaIII (Veltri et al., 2000). The CSN1S2 F allele is characterized by a G13C transition occurring at exon 3, which results in an amino acid substitution $\mathrm{Val}_{7} \rightarrow$ Ile. This variant was detected by PCR amplification (primer pair CASFF/CASFR) and digestion with the restriction enzyme BsmaI (Ramunno et al., 2001). Primer sequences are reported in Table 1. All the PCR amplification protocols were performed in a reaction mixture of $25 \mu \mathrm{l}$ final volume, where $100 \mathrm{ng}$ genomic DNA was amplified with $0.2 \mu \mathrm{M}$ of each primer, $1.5 \mathrm{mM} \mathrm{MgCl}, 0.2 \mathrm{mM}$ dNTPs, $1 \mathrm{x}$ reaction buffer $\left(20 \mathrm{mM}\right.$ Tris-HCl, pH 8.4, $50 \mathrm{mM} \mathrm{KCl}$ ) and $1 \mathrm{U}$ Taq Polymerase (Platinum ${ }^{\circledR}$ Taq DNA Polymerase, Invitrogen, Italy). PCR was performed on a Mastercycler ${ }^{\circledR}$ ep gradient S Thermal Cycler (Eppendorf, Italy), and consisted of an initial denaturation step at $94^{\circ} \mathrm{C}$ for $2.5 \mathrm{~min}$, followed by 30 cycles at $94^{\circ} \mathrm{C}$ for $20 \mathrm{sec}$, the appropriate annealing temperatures for each primer pair (Table 1) for $30 \mathrm{sec}$, and $72^{\circ} \mathrm{C}$ for $30 \mathrm{sec}$, with a final extension step at $72^{\circ} \mathrm{C}$ for $10 \mathrm{~min}$. The amplification products were visualized by agarose gel electrophoresis and ethidium bromide staining. 


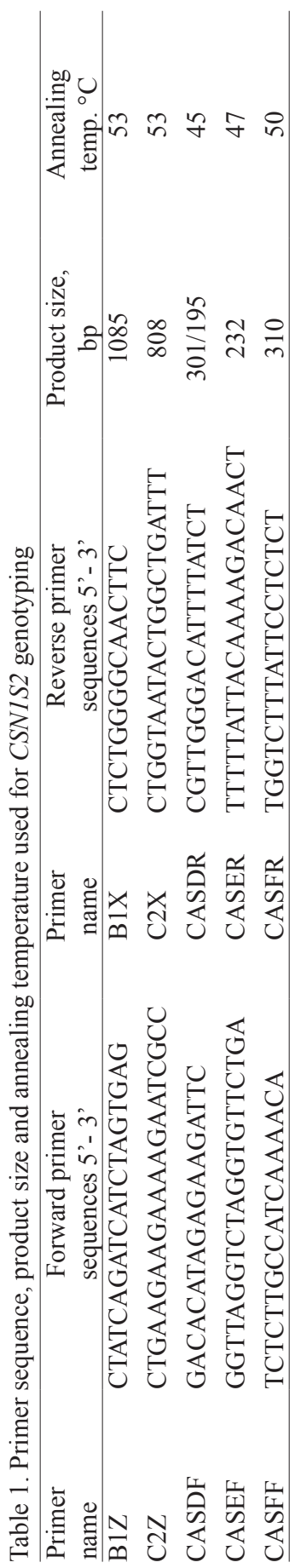




\section{Statistical analysis}

Allele and genotype frequencies and Hardy-Weinberg equilibrium were calculated using Genepop software (Raymond and Rousset, 1995). Analysis of variance was performed using Minitab statistical software, Minitab release 13.32 (Minitab Inc. 2000, State College, PA) in order to evidence the effect of the different $\mu \mathrm{s}_{2}$-casein genotypes on milk yield and composition. The model used for all variables was:

$$
\mathrm{Y}_{\mathrm{ij}}=\mu+\mathrm{F}_{\mathrm{i}}+\mathrm{G}_{\mathrm{j}}+\mathrm{ek}_{(\mathrm{ij})}
$$

where: $Y_{i j}$ - each milk parameter, $\mu$ - general mean, $F_{i}$ - the fixed effect of flock $(\mathrm{i}=20), \mathrm{G}_{\mathrm{j}}$ - the random effect of each individual goat $(\mathrm{j}=220)$, $\mathrm{ek}_{(\mathrm{ij})}$ - error effect.

For all parameters, model effects were declared significant at $\mathrm{P}<0.05$. Prior to this, SCC and TMC had been transformed into logarithmic form to normalize the distribution of their frequencies (Snedecor and Cochran, 1980).

\section{RESULTS}

Allele and genotype frequencies at the CSN1S2 locus are reported in Table 2. F and A alleles were the most prevalent ( 0.330 and 0.400 , respectively), B showed the lowest frequency $(0.005)$ as it was identified, in heterozygosis, in

Table 2. Allele and genotype frequencies at CSN1S2 locus in the Sarda goat $(\mathrm{n}=220)$

\begin{tabular}{lccrc}
\hline Allele & Frequency & Genotype & $\mathrm{n}$ & Frequency, \% \\
\hline A & 0.330 & AA & 30 & 13.6 \\
B & 0.005 & AB & 2 & 0.9 \\
C & 0.200 & AC & 18 & 8.2 \\
E & 0.065 & AE & 7 & 3.2 \\
F & 0.400 & AF & 58 & 26.4 \\
& & CC & 5 & 2.3 \\
& & CE & 5 & 2.3 \\
& & CF & 55 & 25.0 \\
& & EF & 17 & 7.7 \\
& & FF & 23 & 10.5 \\
\hline
\end{tabular}

only two goats, while $\mathrm{D}$ and 0 alleles were not detected. On the whole, 10 different genotypes were identified. AF and CF, with a frequency of 26.4 and $25 \%$, respectively, were the most common, as the sum of their frequencies represented more than $50 \%$ of the examined samples. 


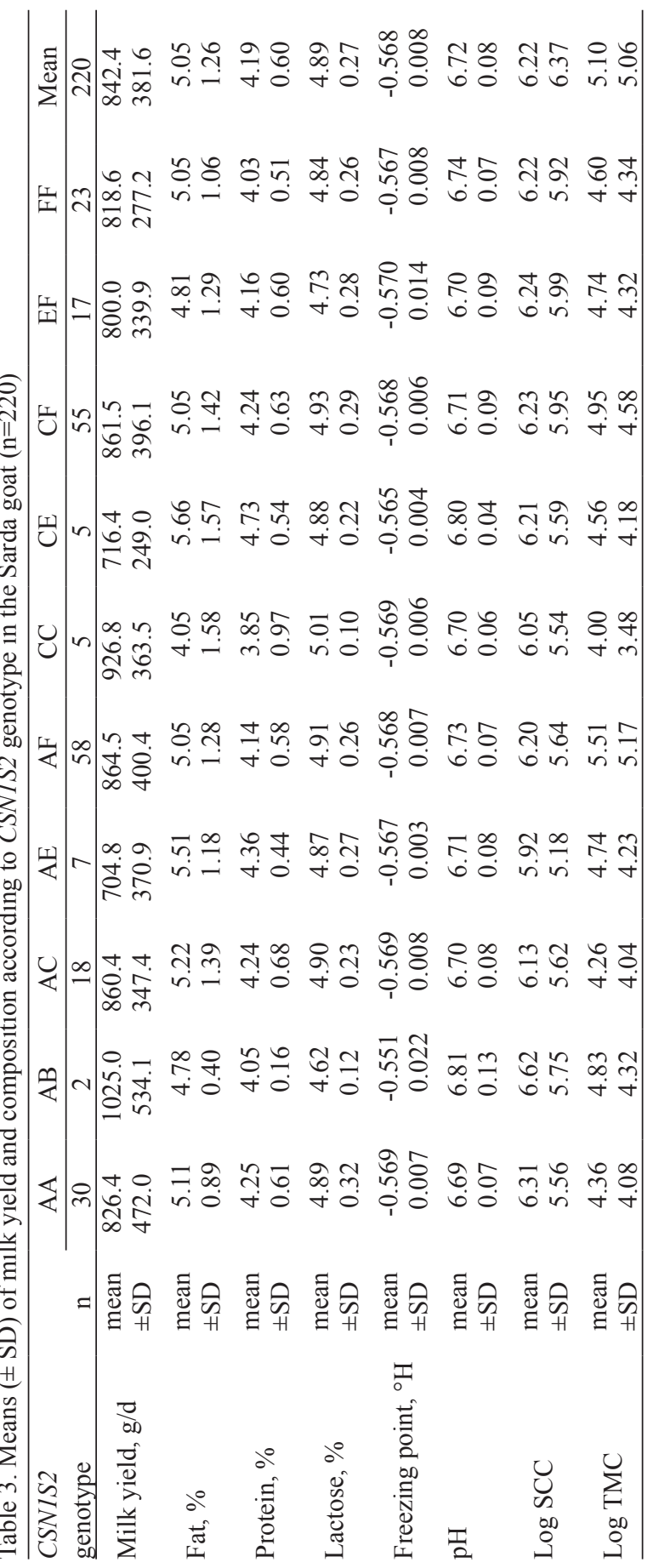


Daily milk yield, chemical and physical composition, SCC and TMC according to genotype are summarized in Table 3. Statistical analysis did not evidence any difference among the genotypes. Average daily milk yield was $840 \mathrm{~g}$, fat, average protein and lactose percentage were 5.05, 4.19 and 4.89\%, respectively. Mean values of freezing point and $\mathrm{pH}$ were $-0.568^{\circ} \mathrm{H}$ and 6.72. TMC logarithm was 5.10 and SCC logarithm 6.22.

\section{DISCUSSION}

Genotype frequencies of $\mathrm{AF}$ and $\mathrm{CF}$ were higher than those recorded by Ramunno et al. (2000) in a local goat breed reared in the south of Italy, in which AA genotype has the highest frequency (22.5\%). Analysis of allele frequencies, in accordance with the Hardy-Weinberg law, indicated that the examined population was in disequilibrium because of a heterozygote excess. Marletta et al. (2005) also describe a disequilibrium at CSN1S2 in Girgentana goats, but that is due to a heterozygote deficiency. The allele frequencies recorded for $\mathrm{F}, \mathrm{A}$ and $\mathrm{C}$ were similar to those by Sacchi et al. (2005) in several Mediterranean goat breeds. Bouniol et al. (1994), in Alpine and Saanen goat breeds, register the highest frequency for the CSN1S2 A allele (0.85) and the lowest for the $\mathrm{C}$ allele (0.11). In our study, allele frequencies of CSN1S2 B and E were lower than those evidenced by Sacchi et al. (2005) in several Italian goat breeds. The defective $\mathrm{D}$ and 0 alleles were not identified in this study. Both alleles show a frequency lower than 0.05 in two studies by Sacchi et al. (2005) and Marletta et al. (2005) while a very high frequency of the 0 allele $(0.15)$ has been reported in a population of Hungarian dairy goats (Kusza et al., 2007).

The polymorphisms occurring at a casein locus have to be considered in the contest of the casein gene cluster, using information deriving from the entire casein haplotype (Hayes et al., 2006; Finocchiaro et al., 2008). The goats analysed in this study showed the occurrence of defective alleles at the CSN1S1 locus, coding for $\alpha \mathrm{s}_{1}$-casein, such as the F, E, 01 and $\mathrm{N}$ alleles, and also at the CSN2 locus, coding for $\beta$-casein, such as the 01 allele (Vacca, unpublished). These variants were also detected in bucks from the Sarda breed (Vacca et al., 2005).

Daily milk yield was lower, but fat and protein content were higher than those recently registered by the Italian breeders Association (AIA) for specialized breeds reared in Italy, like Saanen and Alpine (http://www.aia.it/bollettino/bollettino. htm), and by several authors (Haenlein, 2007; Morand-Fehr et al., 2007). These results agree with previous studies on the Sarda goat (Tziboula-Clarke, 2003; Macciotta et al., 2005; Morand-Fehr et al., 2007) and are similar to those recorded by Galal (2005) for other non-specialized local goat breeds. TMC value, which is 
considered an excellent parameter for assessing flock hygiene and health, was low, considering hand-milking and inadequate facilities on the farms. This statement is confirmed by the results regarding SCC values, which seem to be high if compared to other dairy species like cows or sheep, but are similar to those recorded in other goat breeds reared with extensive and intensive methods (Fekadu et al., 2005).

\section{CONCLUSIONS}

The present studies show that the $\alpha_{2}$-casein genotype did not affect any parameter and we can suppose this was due to the absence of the null and intermediate alleles. This feature indicates that the milk from Sarda goats is suitable for cheese making. Moreover, it could be interesting to continue the research in order to detect defective alleles in the Sarda breed, as goats carrying null and intermediate alleles will allow the production of drinking milk for people who are allergic or intolerant of cow's $\alpha_{2}$-casein.

\section{REFERENCES}

Barbieri M.E., Manfredi E., Elsen J.M., Ricordeau G., Bouillon J., Grosclaude F., Mahé M.F., Bibé B., 1995. Influence du locus de la caséine $\alpha_{\mathrm{s} 1}$ sur les performances laitières et les paramètres génétiques des chèvres de race Alpine. Genet. Sel. Evol. 27, 437-450

Bouniol C., Brignon G., Mahé M.F., Printz C., 1994. Biochemical and genetic analysis of variant C of caprine $\alpha_{2}$-casein (Capra hircus). Anim. Genet. 25, 173-177

Boyazoglu J., Hatziminaoglou I., Morand-Fehr P., 2005. The role of the goat in society: past, present and perspectives for the future. Small Ruminant Res. 60, 13-23

Carcangiu V., Mura M.C., Vacca G.M., Bini P.P., 2006. Sardinian goat breeding and utilisation of environmental resources. In: Animal Products from the Mediterranean Area. EAAP Publication No. 119. Wageningen Academic Publishers (The Netherlands), pp. 249-254

Caroli A., Chiatti F., Chessa S., Rignanese D., Bolla P., Pagnacco G., 2006. Focusing on the goat casein complex. J. Dairy Sci. 89, 3178-3187

El-Agamy E.I., 2007. The challenge of cow milk protein allergy. Small Ruminant Res. 68, 64-72

Fekadu B., Soryal K., Zeng S., Van Hekken D., Bah B., Villaquiran M., 2005. Changes in goat milk composition during lactation and their effect on yield and quality of hard and semi-hard cheeses. Small Ruminant Res. 59, 55-63

Finocchiaro R., Hayes B.J., Siwek M., Spelman R.J., van Kaam J.B.C.H.M., Ådnøy T., Portolano B., 2008. Comparison of casein haplotypes between two geographically distant European dairy goat breeds. J. Anim. Breed. Genet. 125, 68-72

Galal S., 2005. Biodiversity in goats. Small Ruminant Res. 60, 75-81

Groenen M.A.M., Dijkhof R.J.M., Verstege A.J.M., van der Poel J.J., 1993. The complete sequence

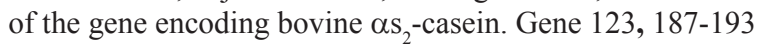

Haenlein, G.F.W., 2007. About the evolution of goat and sheep milk production. Small Ruminant Res. 68, 3-6 
Hayes B., Hagesæther N., Ådnøy T., Pellerud G., Berg P.R., Lien S., 2006. Effects on production traits of haplotypes among casein genes in Norwegian goats and evidence for a site of preferential recombination. Genetics 174, 455-464

Jarvinen K.M., Beyer K., Vila L., Chatchatee P., Busse P.J., Sampson H.A., 2002. B-cell epitopes as a screening instrument for persistent cow's milk allergy. J. Alleg. Clin. Immunol. 110, 293-297

Kusza S., Veress G., Kukovics S., Jávor A., Sanchez A., Angiolillo A., Bösze A., 2007. Genetic polymorphism of $\alpha \mathrm{s}_{1}-$ and $\alpha \mathrm{s}_{2}$-caseins in Hungarian milking goats. Small Ruminant Res. 68, 329-332

Macciotta N.P.P., Fresi P., Usai G., Cappio-Borlino A., 2005. Lactation curves of Sarda breed goats estimated with test day models. J. Dairy Res. 72, 1-6

Marletta D., Bordonaro S., Guastella A.M., Criscione A., D’Urso G., 2005. Genetic polymorphism of the calcium sensitive casein in Sicilian Girgentana and Argentata dell'Etna goat breeds. Small Ruminant Res. 57, 133-139

Martin P., Brignon G., Furet J.P., Leroux C., 1996. The gene encoding $\alpha \mathrm{s}_{1}$-casein is expressed in human mammary epithelial cells during lactation. Lait 76, 526-537

Morand-Fehr P., Fedele V., Decandia M., Le Frileux Y., 2007. Influence of farming and feeding systems on composition and quality of goat and sheep milk. Small Ruminant Res. 68, 20-34

Ramunno L., Cosenza G., Pappalardo M., Longobardi E., Gallo D., Pastore N., Di Gregorio P., Rando A., 2001. Characterization of two new alleles at the goat CSN1S2 locus. Anim. Genet. 32, 264-268

Ramunno L., Pappalardo M., Cosenza G., Pastore N., Gallo D., Grimaldi G., Rubino R., Calandrelli M., Rando A., 2000. Genetic characterization at $\alpha_{\mathrm{S} 1}, \beta$ and $\alpha_{\mathrm{S} 2}$ loci of a goat population reared in the Sorrentine Peninsula. In: Proceedings of the XIV Congress SIPAOC (Italian Society of Pathology and Breeding of Sheep and Goat). Vietri sul mare, Salerno (Italy), pp. 321-324

Ramunno L., Pauciullo A., Mancusi A., Cosenza G., Mariani P., Malacarne M., 2007. Influence of genetic polymorphism of calcium-sensitive caseins on structural, nutritional, renneting and hypoallergenic properties of goat milk. Sci. Tech. Lattiero-Casearia 58, 257-271

Rijnkels M., 2002. Multispecies comparison of the casein gene loci and evolution of casein gene family. J. Mammary Gland Biol. 7, 327-345

Rijnkels M., Elnitski L., Miller W., Rosen J.M., 2003. Multispecies comparative analysis of a mammalian-specific genomic domain encoding secretory proteins. Genomics 82, 417-432

Sacchi P., Chessa S., Budelli E., Bolla P., Ceriotti G., Soglia D., Rasero R., Cauvin E., Caroli A., 2005. Casein haplotype structure in five Italian goat breeds. J. Dairy Sci. 88, 1561-1568

Snedecor G.W., Cochran W.G., 1980. Statistical Methods. 7th Edition. The Iowa State University Press. Ames, IA

Threadgill D.W., Womack J.E., 1990. Genomic analysis of the major bovine milk protein genes. Nucl. Acid Res. 18, 6935-6942

Tziboula-Clarke A., 2003. Goat milk. In: H. Roginski, J.W. Fuquay, P.F. Fox (Editors). Encyclopedia of Dairy Sciences. Academic Press. Cornwall (UK), pp. 1270-1279

Vacca G.M., Dettori M.L., Sanna M., Porqueddu M., Carcangiu V., 2005. Polymorphism of the CSN1S1, CSN1S2 and CSN2 genes in Sarda bucks. In: Proceedings of the $16^{\text {th }}$ ASPA Congress. Turin (Italy), p. 116

Veltri C., Lagonigro R., Pietrolà E., D’Andrea M., Pilla F., Chianese L., 2000. Molecular characterisation of the goat $\alpha_{2}$-casein $\mathrm{E}$ allele and its detection in goat breeds of Italy. In: Proceedings of the $7^{\text {th }}$ International Conference on Goats. Tours (France), p. 727 